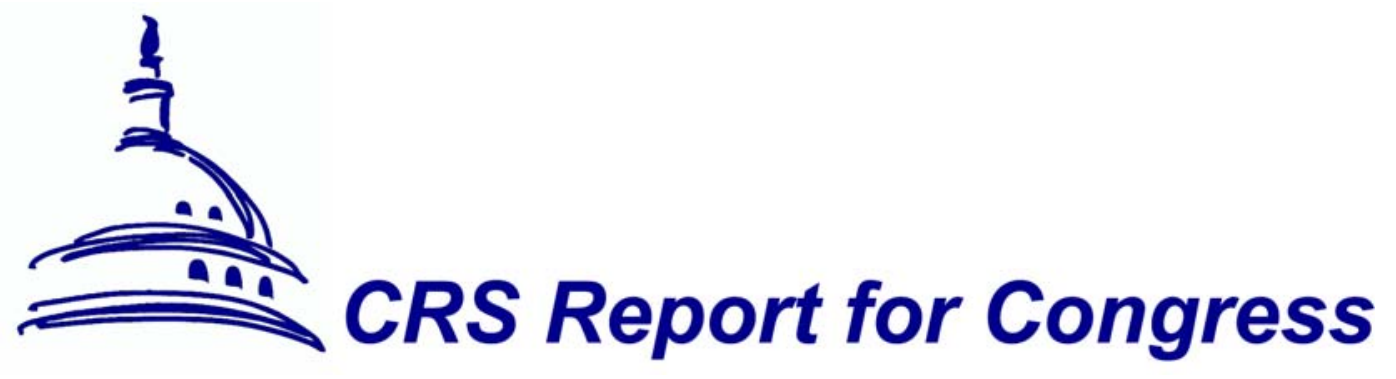

Order Code RS21846

Updated April 18, 2007

\title{
U.S.-Bahrain Free Trade Agreement
}

\author{
Martin A. Weiss \\ Analyst in International Trade and Finance \\ Foreign Affairs, Defense, and Trade Division
}

\section{Summary}

U.S. Trade Representative Robert B. Zoellick signed the U.S.-Bahrain Free Trade Agreement (FTA) on September 14, 2004. The implementing legislation was passed by the House on December 7, 2005, and passed by the Senate and cleared for the White House on December 13, 2005. The agreement was signed into law by the President on January 11, 2006, as the United States-Bahrain Free Trade Agreement Implementation Act (P.L. 109-169).

Under the agreement, all bilateral trade in consumer and industrial goods will be duty free and $98 \%$ of U.S. agricultural exports will be duty free. The FTA is to support economic reform, both within Bahrain, and throughout the Middle East. This report will be updated as events warrant. For more information on Bahrain's politics, security, and US policy, see CRS Report 95-1013, Bahrain: Reform, Security, and U.S. Policy, by Kenneth Katzman.

\section{Introduction}

On September 14, 2004, U.S. Trade Representative Robert B. Zoellick signed a free trade agreement (FTA) between Bahrain and the United States. Formal negotiations were launched in Manama, Bahrain on January 26, 2004, and were completed on May 27, 2004. The House Ways and Means Committee approved draft legislation implementing the agreement on November 3, 2005, with no amendments. Following approval of the draft legislation by the Senate Finance Committee on November 9, the Administration submitted implementing legislation (S. 2027/H.R. 4340) on November 16. Formal approval of the implementing legislation was given in separate votes by the House Ways and Means Committee and the Senate Finance Committee on November 18. The implementing legislation was passed by the House on December 7 and passed by the Senate and cleared for the White House on December 13. The agreement was signed into law by the President on January 11, 2006, as the United States-Bahrain Free Trade Agreement Implementation Act (P.L. 109-169). 
The agreement entered into force on August 1, 2006, following the passage of legislation in Bahrain providing increased intellectual property rights (IPR) protection. According to the Bahrain-based Gulf Daily News, six new IPR laws were passed by both houses of Bahrain's parliament. ${ }^{1}$ The agreement entered into force following approval of the new laws by King Hamad bin Isa Al Khalifa.

In the United States, the AFL/CIO provided the only significant opposition to the Agreement. Some House Democrats expressed labor concerns during the November $3^{\text {rd }}$ vote but eventually supported the agreement after receiving assurances from the Bahraini government that they would make progress on new legislation offering additional labor protections. The FTA is supported by the National Association of Manufacturers, the Bankers' Association for Finance and Trade, the Motion Picture Association of America, and PhRMA, the association of pharmaceutical manufacturers, among other groups. ${ }^{2}$

There has been some dissent in the Middle East region over the U.S.-Bahrain FTA. Saudi Arabia, a member of the Gulf Co-operation Council (GCC), ${ }^{3}$ has alleged that GCC countries that sign bilateral trade agreements with the United States violate a GCC economic agreement that members cannot grant greater trade preferences to non-GCC countries. According to press reports, Saudi Arabia has threatened imposing a 5\% duty on any U.S. goods that are imported into the GCC and then exported to Saudi Arabia. According to one source, Saudi Arabia may be concerned that U.S. agricultural products, especially wheat, may be exported to Saudi Arabia via other GCC countries such as Bahrain. Bahrain officials have argued that Saudi Arabia has not contested other bilateral FTAs that Bahrain has signed, and alleges that Saudi Arabia's complaints are political, not economic, in nature. ${ }^{4}$

Domestically, some analysts have raised concern that the U.S. government strategy of completing FTAs with countries such as Bahrain, whose U.S. trade is relatively small, is not necessarily the best use of USTR's resources. ${ }^{5}$ Others argue that the USTR should be investing more resources into potentially more economically significant agreements such as the proposed Free Trade Area of the Americas (FTAA). The Administration contends that its FTA agreements are effective as building blocks to future agreements and increased political and economic reform.

\section{Why Bahrain?}

Many attribute Bahrain's selection as the first U.S. free trade agreement in the Persian Gulf to (1) the strong U.S.-Bahrain political military relationship, and (2)

${ }^{1}$ Mohammed Al A'Ali, "FTA clears last hurdle with Shura go-ahead", Gulf Daily News, May 9, 2006.

${ }^{2}$ Elizabeth Becker, "U.S. and Bahrain Reach a Free Trade Agreement," New York Times, May 28, 2004.

${ }^{3}$ Other GCC members are Bahrain, Oman, the United Arab Emirates (UAE), Kuwait, and Qatar

4 "Saudi Arabia Threatens Tariff Hikes in Retaliation for U.S. Middle East FTAs," Inside U.S. Trade, January 28, 2005.

${ }^{5}$ See General Accounting Office (GAO) Report, GAO-04-233 International Trade, Intensifying Free Trade Negotiating Agenda Calls for Better Allocation of Staff and Resources, January 2004. 


\section{CRS-3}

political and economic reform in Bahrain. This FTA is intended to be a building block for President Bush and Congress's Middle East free trade initiatives. ${ }^{6}$

U.S.-Bahrain Political/Military Relationship. Bahrain is a close U.S. partner in the Persian Gulf. It consists of 35 islands along the Persian Gulf between the east coast of Saudi Arabia and Qatar along the Persian Gulf. Virtually its entire domestic population of 667,000 is Muslim (70 \% Shi'a/30\% Sunni). It is a constitutional monarchy, ruled by the al-Khalifa family since 1783 .

Bahrain has hosted a U.S. military presence since World War II. It currently hosts the Fifth Fleet, which is the headquarters for the U.S. Persian Gulf naval forces. The Fifth Fleet headquarters is a command and administrative facility only; no U.S. warships are actually based in Bahrain's ports. In October 2001, Bahrain was designated a Major NonNATO Ally (MNNA). ${ }^{7}$ Bahrain endorsed the U.S. campaign in Afghanistan and deployed a frigate to support allied operations during Operation Enduring Freedom. While Bahrain did not endorse the Iraq campaign, King al-Khalifa did not criticize it.

Political Reform and the Bahraini Economy. King al-Khalifa, installed in 1999, has pushed for political and economic liberalization. In February 2001, Bahraini voters approved a referendum on the National Action Charter - the centerpiece of the King's political liberalization program. Since then, parliamentary elections have been held (October 2002), and in December 2002, the first legislative session since 1975 took place.

Oil was discovered in Bahrain in 1932 by Standard Oil Company of California. Current production is around 40,000 barrels per day (b/d). The Bahrain National Gas Company operates a gas liquification plant that utilizes gas piped directly from Bahrain's oilfields. Gas reserves should last about 50 years at present rates of consumption. Revenues from oil and natural gas currently account for $16.5 \%$ of GDP and provide about $60 \%$ of government income. Among the Cooperation Council of the Arab States of the Gulf (GCC) - Bahrain, Kuwait, Oman, Qatar, Saudi Arabia, and the United Arab Emirates - Bahrain has the smallest proven oil reserves. The International Monetary Fund (IMF) estimates that Bahrain will run out of petroleum in 2018 if pumping continues at current levels. ${ }^{8}$ Bahrain and Saudi Arabia share ownership of the Abu Saafa oilfield, and since 1997, Saudi Arabia has given Bahrain the entire proceeds of the 140,000 b/d field.

${ }^{6}$ See CRS Report RL32335, Middle East Trade Initiatives: S. 1121/H.R. 2267 and the Administration's Plan, by Mary Jane Bolle.

${ }^{7}$ MNNA Status does not entail the same mutual defense and security guarantees afforded to North Atlantic Treaty Organization (NATO) members. Title 10 U.S. Code Section 2350a authorizes the Secretary of Defense, with the concurrence of the Secretary of State, to designate MNNAs for purposes of participating with the Department of Defense (DOD) in cooperative research and development programs. Section 517 of the Foreign Assistance Act of 1961 (FAA), as amended, authorizes the President to designate a country as a MNNA after 30-days notification to Congress, for purposes of the FAA and the Arms Export Control Act (AECA).

${ }^{8}$ Ugo Fasano and Zubair Iqbal, GCC Countries: From Oil Dependence to Diversification, International Monetary Fund, 2003. 


\section{CRS-4}

Financial institutions operate in Bahrain, both offshore and onshore, ${ }^{9}$ without impediments, and the financial sector is currently the second largest contributor to GDP. There are no restrictions on capital flows. More than 100 offshore banking units and representative offices are located in Bahrain, as well as 65 American firms. In the past two years, Bahrain has passed laws liberalizing foreign property ownership and tightening its anti-money laundering laws.

Bahrain is the United States' $88^{\text {th }}$ largest goods export market. In 2005, U.S. exports to Bahrain were $\$ 351$ million, up $16.2 \%$ from 2004. Aircraft, miscellaneous manufactures and agricultural products account for the majority of U.S. exports. U.S. imports from Bahrain in 2005 were $\$ 432$ million, a 6.5\% increase from 2004. Since tariffs between the United States and Bahrain are already low, the USTR estimates that the FTA will have little effect on U.S. imports from Bahrain.

As a member of the Arab League, trade between Bahrain and Israel is technically subject to the Arab League boycott of Israel. ${ }^{10}$ However, in the case of Bahrain, the boycott is not strictly enforced and of little commercial significance. The Arab League boycott of Israel was raised at a June 2003 joint press conference by USTR Robert Zoellick and Bahraini Minister of Finance Abdullah Saif. Both Ambassador Zoellick and Minister Saif stressed that Bahrain was a member in good standing of the WTO, which does not permit boycotts of any kind. Nonetheless, neither specifically addressed if Bahrain would officially remove itself from the boycott. ${ }^{11}$ In September 2005, Bahrain announced that it will make efforts to remove the boycott. According to Bahrain's Treasurer, Ahmed bin Mohammed Al-Khalifa, "Bahrain recognizes the need to withdraw the primary boycott against Israel and is developing the means to achieve this."12

Promoting Middle Eastern Economic Reform. In May 2003, President Bush announced his goal of creating a free trade area of the Middle East by 2013, by accumulating bilateral agreements with individual countries in the region. A Middle East Free Trade Area (MEFTA) is an Administration strategy to create a free trade area among 20 Middle Eastern and North African countries and the United States by 2013. Currently, the United States has FTAs in force with Bahrain, Jordan, Morocco, and Israel. The proposed MEFTA plan was announced by President Bush on May 9, 2003. ${ }^{13}$ The United States also plans to expand its network of trade and investment framework agreements (TIFAs) and bilateral investment treaties (BITs) throughout the region. ${ }^{14}$

${ }^{9}$ Onshore financing is the provision of financial services to residents, offshore finance is the provision to non-residents.

${ }^{10}$ CRS Report RL33961, Arab League Boycott of Israel, by Martin A. Weiss.

${ }^{11}$ In September 1994, Bahrain and the other five Persian Gulf monarchies agreed to stop enforcing the secondary and tertiary boycotts while retaining the primary (direct) boycott.

${ }^{12}$ Yoav Stern, "Bahrain tells U.S. it is repealing anti-Israel boycott," Haaretz Online, September 19, 2005.

${ }^{13}$ CRS Report RL32638: Middle East Free Trade Area: Progress Report, by Mary Jane Bolle.

${ }^{14}$ Office of the United States Trade Representative, "Middle East Trade Initiative: Trade Facts," June 23, 2003. 


\section{Key Provisions ${ }^{15}$}

The FTA negotiations included thirteen working groups: Services, Financial Services, Telecommunications and E-Commerce, Sanitary and Phytosanitary Measures (SPS), Environment, Government Procurement, Legal, Technical Barriers to Trade (TBT), Customs, Market Access (both industrial and agricultural products), Intellectual Property Rights (IPR), Textiles, and Labor.

The FTA eliminates tariffs on all consumer and industrial products. For agricultural products, $98 \%$ of U.S. exports to Bahrain are now duty free, with 10-year phase-outs for the remaining items. Textiles and apparel trade will be duty free immediately if the product contains either U.S. or Bahraini yarn. A temporary transitional allowance would allow duty free trade in products that do not yet meet these standards.

Services. According to the USTR, the agreement provides U.S. firms among the highest degree of access to service markets of any U.S. FTA to date. Key services sectors covered by the agreement include audiovisual, express delivery, telecommunications, computer and related services, distribution, healthcare, services incidental to mining, construction, architecture and engineering. U.S. financial service suppliers will have the right to establish subsidiaries, branches, and joint ventures in Bahrain and enjoy the benefits of strong regulatory transparency, including prior notice and comment and license approval within 120 days. For life and medical insurance, Bahrain agreed to allow access upon entry into force of the Agreement, and for non-life insurance will allow access within six months after entry into force of the Agreement. Bahrain has agreed that in revising its insurance laws and regulations, it will not discriminate against U.S. insurance suppliers and will allow existing insurance suppliers to continue current business activities.

The agreement underscores Bahrain's open and developed financial sector, which includes both conventional and Islamic financial services. Bahrain will allow U.S.-based firms to offer services cross-border to Bahrainis in areas such as financial information and data processing, and financial advisory services. Bahrain will also allow U.S.-based asset managers (including insurance companies) to manage the portfolios of collective investment schemes established in Bahrain.

Under the FTA, each government agreed that users of the telecom network will have reasonable and nondiscriminatory access to the network, preventing local firms from having preferential or "first right" of access to telecom networks. U.S. phone companies will have the right to interconnect with former monopoly networks in Bahrain at nondiscriminatory, cost-based rates, and will be able to build a physical network in Bahrain with nondiscriminatory access to key facilities, such as telephone switches and submarine cable landing stations.

Intellectual Property Rights (IPR). The Agreement requires each government to criminalize end-user piracy, providing strong deterrence against piracy and counterfeiting. Each government commits to having and maintaining authority to seize,

${ }^{15}$ Office of the United States Trade Representative, "Free Trade With Bahrain: Trade Facts," May 27, 2004. 
forfeit, and destroy counterfeit and pirated goods and the equipment used to produce them. IPR laws will be enforced against goods-in-transit, to deter violators from using U.S. or Bahraini ports or free-trade zones to traffic in pirated products. Ex officio action may be taken in border and criminal IPR cases, thus providing more effective enforcement. The Agreement mandates both statutory and actual damages under Bahraini law for IPR violations, which will deter piracy. Under these provisions, monetary damages can be awarded even if actual economic harm (retail value, profits made by violators) cannot be determined.

According to both countries, the intellectual property chapter does not "affect the ability of either Party to take necessary measures to protect public health by promoting access to medicines for all, in particular concerning cases such as HIV/AIDS, tuberculosis, malaria, and other epidemics as well as circumstances of extreme urgency or national emergency." The FTA also expressly states that it will not prevent effective utilization of the 2003 WTO consensus allowing developing countries that lack pharmaceutical manufacturing capacity to import drugs under compulsory licenses. ${ }^{16}$

Workers Rights. According to the Bush Administration, the agreement fully meets the labor objectives set out by the Congress. Labor obligations are part of the core text of the Agreement. Each government commits to strive to ensure that its laws provide for labor standards consistent with internationally recognized labor rights. The Agreement includes a cooperative mechanism to promote respect for the principles embodied in the ILO Declaration on Fundamental Principles and Rights at Work, and compliance with ILO Convention 182 on the Worst Forms of Child Labor. The labor ministries, together with other appropriate agencies, agree to establish priorities and develop specific cooperative activities.

Labor rights have been arguably the only major area of contention. Several Members of Congress and the AFL-CIO have criticized Bahrain for not making enough advances in reforming its labor laws. Issues of concern include a ban on workers in the same company forming more than one union, laws regarding penalties for anti-union discrimination, the ability of companies to withhold foreign workers' salaries for up to three months, and restrictions on unions calling strikes. However, Bahrain has introduced reforms and recently agreed to apply International Labor Organization (ILO) and to introduce labor law changes to make its laws fully ILO-consistent. ${ }^{17}$

\footnotetext{
${ }^{16}$ Office of the United States Trade Representative, "U.S.-Bahrain FTA: Fact Sheet on Access to Medicines," September 14, 2004.

${ }^{17}$ Washington Trade Daily, November 17, 2006.
} 